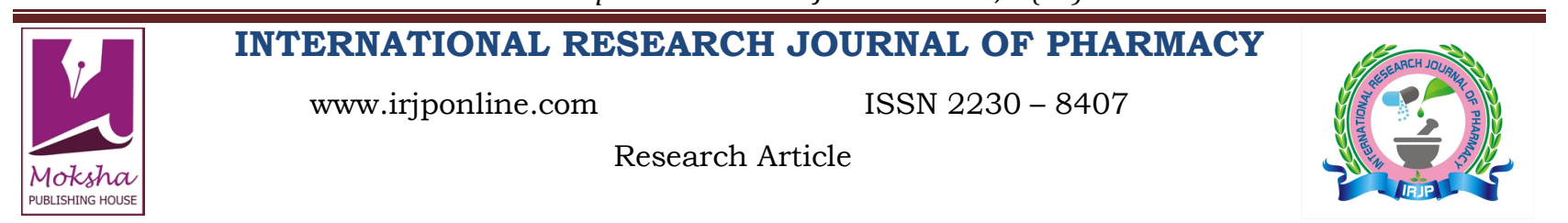

\title{
CENTRAL ANTINOCICEPTIVE EFFECT OF DIFFERENT EXTRACTS OF SARACA ASOCA SEEDS ASSESSED USING HOTPLATE AND TAIL IMMERSION METHODS
}

Mradu Gupta ${ }^{1}$, Saumyakanti Sasmal ${ }^{1}$, Arup Mukherjee Gupta ${ }^{2}$.

${ }^{1}$ Dravyaguna Department, Institute of Post Graduate Ayurvedic Education and Research, Kolkata, West Bengal, India

${ }^{2}$ Department of Chemical Technology, University College of Science and Technology, Calcutta University, Kolkata, West Bengal, India

*Corresponding Author Email: mradu_gupta@hotmail.com

Article Received on: 10/09/13 Revised on: 07/10/13 Approved for publication: 20/10/13

DOI: $10.7897 / 2230-8407.041021$

IRJP is an official publication of Moksha Publishing House. Website: www.mokshaph.com

(C) All rights reserved.

\section{ABSTRACT}

The stem bark of Ashoka (Saraca asoca) plant has been traditionally used for a number of therapeutic purposes including anti-inflammatory activities. It has been described in ancient Ayurvedic texts as an analgesic also but rampant use of its stem bark has affected the plant population although its seeds are available in plenty. This research effort aims to examine the central analgesic effect of acetone, methanol and aqueous extracts of the powder of Asoka seeds to validate its antinociceptive properties described in the literature. Apart from the standard pharmacognosy and phyto-chemical examination, acute toxicity studies were carried out on all the extracts before assessing the central analgesic effect using the standard techniques of hot plate and tail immersion methods. Morphine Sulphate was used as the standard drug in both these cases. During phytochemical analysis, flavonoids, polyphenols, tannins and saponins were found in the plant extracts while no significant morbidity or any mortality was noticed during the toxicity studies. All the extracts exhibited significant central analgesic effect at doses of $300 \mathrm{mg} / \mathrm{kg}$ and $500 \mathrm{mg} / \mathrm{kg}$ as compared to the control group, the antinociceptive efficacy being greater at the higher drug dose. The highest analgesic effect was observed in case of aqueous extract, followed by acetone extract and the lowest in case of methanol extract. The therapeutic efficacy at higher dosage of aqueous extract was comparable to but lower compared to the standard drug. However, the analgesic effect of the drug extracts persisted for a longer time than the standard drug, validating its comparable and sustained analgesic effect.

Keywords: Saraca asoca, antinociceptive, analgesic, tail immersion, hot plate

\section{INTRODUCTION}

The use of medicinal plants for both preventive and curative aspects has been commonplace since ancient times in many parts of the world. Different forms of herbal therapies using either the herb products or pure extracts are nowadays very popular. Among other ailments, considering the importance of pain in the personal and professional life of the people, pain relief has always been a major area of concern for many physicians and researchers in biological sciences. In view of the financial costs imposed upon the society due to pain relief treatments combined with the knowledge about the numerous side effects of the available analgesics in the market, there exists a strong-felt need for a safe analgesic herbal drug. The ancient Ayurvedic text book Charak Samhita mentions a number of specific herbs under the chapter titled Vednasthapan Mahakashay which are known to possess therapeutic properties to reduce pain in various body parts ${ }^{1-3}$. Among these herbs, the stem bark of the well-known medicinal plant Asoka (Saraca asoca) has been prescribed for the treatment of uterine and urinary disorders, and as an astringent, anti-inflammatory, coolant $\mathrm{etc}^{4-5}$. However, rampant use of the stem bark of this important medicinal plant has affected the number of trees available over time. On the other hand, its seeds are widely available in large numbers and they could possess similar properties as indicated in the literature review. The present research work was done to evaluate the central analgesic / antinociceptive effect of the different extracts of the seeds of Saraca asoca using the two well-established pharmacological techniques for this purpose.

\section{MATERIALS AND METHODS}

The chemical analysis and experimental study were done in the laboratory and CPCSEA registered animal facility of department of Dravyaguna of the Institute of Post Graduate
Ayurvedic Education and Research (IPGAE and R), Kolkata, India.

\section{Collection and Identification of Plant materials}

Fresh seeds of Saraca asoca were purchased from the medicinal plant garden, Narendrapur Ramkrishna Mission, Kolkata, India and State Government Herbal Garden at Kalyani, West Bengal, India and dried under sunlight. These seeds were authenticated at the Botanical Survey of India, Howrah, India vide Ref No- BSI/CNH/AD/Tech/2010, dated21.07.2010. An authentic specimen was deposited in the herbarium museum of the department of Dravyaguna, IPGAE and R, Kolkata, India for future reference.

\section{Chemicals}

All the chemicals used for different chemical and pharmacological studies were of analytical grade and obtained from M/s Jagsonpal Pharmaceuticals Ltd., Rudrapur, Uttarakhand, India. The standard drug Morphine was procured from the excise department of Govt. of West Bengal, India.

\section{Pharmacognostic studies}

Fresh seeds, authenticated from the Botanical Survey of India (BSI), were taken for morphological and histological studies. Coarse powder (\#40mesh) was used to find out different pharmacognostical (macroscopic and microscopic) characteristics in the department of Dravyaguna of IPGAE and $\mathrm{R}$ according to established procedures ${ }^{6-7}$.

\section{Extract preparation}

The seeds of Saraca asoca were washed thoroughly with distilled water to remove dirt and soil. They were further dried in shade for three weeks until a constant weight was obtained, ground into a coarse powder using a domestic 
blender and passed through a \#40 mesh sieve. The extraction was done after the pharmacognostical and physio-chemical analysis of the powder of test sample ${ }^{5}$. This coarse powder was sequentially extracted with petroleum ether $\left(60^{\circ} \mathrm{C}\right.$ $80^{\circ} \mathrm{C}$ ), chloroform, acetone, methanol and water using soxhlet apparatus. These extracts were filtered using a Buckner funnel and Whatman No 1 filter paper at room temperature and concentrated at reduced temperature and pressure using rotary evaporator. All obtained extracts were stored in refrigerator below $10^{\circ} \mathrm{C}$ for subsequent experiments.

\section{Phyto-chemical screening}

The extracts were screened for ascertaining the presence of various chemical constituents like carbohydrates, alkaloids, tannins, flavonoids, glycosides, saponins, fats, proteins and amino acids employing standard screening tests following conventional phyto-chemical screening protocols ${ }^{8-9}$.

\section{Experimental studies}

The toxicity and central analgesic effect of acetone, methanol and aqueous extracts of the seeds of Saraca asoca was assessed on rodent animals after getting approval from the Institutional Animal Ethical Committee (IAEC) in the animal house of IPGAE and $\mathrm{R}$ (registration number 1180/ac/08/CPSEA dated 27.03.2008 of CPCSEA) according to the guidelines of CPCSEA.

\section{Animals}

Swiss albino mice of either sex, weighing about 20-30 g, were used for different in-vivo evaluations. All the animals were procured from M/s Satyacharan Ghosh, Kolkata, the Government of West Bengal, India approved breeder, and housed under standard environmental conditions with fixed $12 \mathrm{~h} \mathrm{light/dark} \mathrm{cycles} \mathrm{and} \mathrm{a} \mathrm{temperature} \mathrm{of} \mathrm{approximately}$ $25^{\circ} \mathrm{C}$ in animal house of IPGAE and R. The animals were kept in standard polypropylene cages and provided with food (standard pellet diet) and water ad libitum. These animals were acclimatized for a period of 14 days prior to performing any experiments ${ }^{10}$. All experimental protocols were approved by IAEC.

\section{Acute toxicity study}

Acute toxicity study was carried out on healthy Swiss albino mice following OECD guideline $423^{11}$. Animals of both sexes were selected by random sampling technique and divided into 5 groups of 3 animals each. A single oral dose of the extract was administered orally at the level of $100 \mathrm{mg}$, $300 \mathrm{mg}, 500 \mathrm{mg}, 700 \mathrm{mg}, 1000$ and $2000 \mathrm{mg} / \mathrm{kg}$ body weight respectively. All the animals were observed for appearance of toxic symptoms including muscle spasm, loss of righting reflex, tremors, behavioural changes, locomotion, convulsions and mortality for 1, 2, 4, 8 and $24 \mathrm{~h}$. Long term supervision was continued for a period of 14 days for observing any occurrence of toxic symptoms and mortality ${ }^{12}$.

\section{Assessment of central analgesic effect}

The central analgesic effect of different extracts was evaluated and compared with the control and standard drug using both the hotplate and the tail immersion methods using the following drug treatment protocol and grouping arrangements of mice:

Group I - Vehicle treated control animals received saline (10 $\mathrm{ml} / \mathrm{kg}$ b.w.)

Group II - Animals received standard drug morphine sulphate (2.5 mg/kg b.w. i.m.)
Group III - Animals received aqueous extract of Saraca asoca (300 mg/kg b.w. p.o.)

Group IV - Animals received aqueous extract of Saraca asoca (500 mg/kg b.w. p.o.)

Group V - Animals received methanol extract of Saraca asoca (300 mg/kg b.w. p.o.)

Group VI - Animals received methanol extract of Saraca asoca (500 mg/kg b.w. p.o.)

Group VII - Animals received acetone extract of Saraca asoca (300 mg/kg b.w. p.o.)

Group VIII - Animals received acetone extract of Saraca asoca $(500 \mathrm{mg} / \mathrm{kg}$ b.w. p.o.)

\section{Tail immersion method}

The tail immersion method was used to assess the central analgesic effect of different drug extracts in different dosages. Overnight fasted mice were divided into eight groups of six each and held in position suitably restrained with the tail extending out. The marked tail $(3 \mathrm{~cm})$ was immersed in the water bath thermo-statistically maintained at $55 \pm 1^{\circ} \mathrm{C}$. The withdrawal time of the tail from hot water (in seconds) was noted as the reaction time or tail flick latency. The maximum cut off time for immersion was 15 seconds to avoid injury to the tissues of the tail. The tail flick response was measured after administration of the test and standard drugs at the time period of $0,30,60$ and 90 minutes. Tail flick latency difference or mean increase in latency after drug administration was used to indicate the analgesia produced by the administered drug ${ }^{13-14}$.

\section{Hot plate method}

Another model for detection of central analgesic activity of the extract of test drug is the Hot Plate method. Here, overnight fasted mice divided into groups (each group having 6 animals) were subjected to thermal stimulus after being administered their assigned treatment drug. The latency in time after applying the thermal stimulus through the hot plate, which was maintained at $55 \pm 1{ }^{\circ} \mathrm{C}$, was measured. The delay in hind paw licking by each animal was recorded in seconds as response immediately before and after 30, 60, 90 and 120 minutes of drug administration. The maximum reaction time of observation was kept at 15 seconds throughout to avoid tissue damage ${ }^{14-15}$.

\section{Statistical analysis}

The obtained experimental data were statistically analyzed using one-way ANOVA test followed by Dunnet's t test for individual comparison of groups with the control ${ }^{10,12}$. Results were expressed as Mean \pm SEM. $\mathrm{p}<0.05$ was used to indicate statistical significance.

\section{RESULTS}

\section{Physiochemical and Phytochemical screening}

During routine physiochemical analysis, the extractive value in $\mathrm{w} / \mathrm{w}$ terms was found to be $1.09 \%, 3.22 \%$ and $1.27 \%$ in case of aqueous, methanol and acetone extracts. Preliminary phytochemical screening of the extracts revealed the presence of carbohydrates, flavonoids, polyphenols, tannins and saponins. However, no alkaloids, proteins or amino acids were usually found present. The results obtained during the phytochemical analysis in respect of the various parameters classes in different extracts of the seeds of Saraca asoca have been presented in Table 1 . 
Mradu Gupta et al. Int. Res. J. Pharm. 2013, 4 (10)

Table 1: Phytochemical Analysis of Different Extracts of Seeds of Saraca asoca

\begin{tabular}{|c|c|c|c|}
\hline Phytochemical constituents' presence & Aqueous Extract & Methanol Extract & Acetone Extract \\
\hline Flavonoids & Present & Present & Present \\
\hline Tannins & Present & Present & Present \\
\hline Alkaloids & Absent & Absent & Absent \\
\hline Saponins & Present & Present & Present \\
\hline Carbohydrates & Present & Present & Present \\
\hline Glycosides & Absent & Absent & Present \\
\hline Proteins and Amino acids & Absent & Absent & Absent \\
\hline Fixed oils and Fats & Absent & Present & Present \\
\hline
\end{tabular}

Table 2: Effect of Drug Treatments upon Central Analgesic Activity Using Tail Immersion Model

\begin{tabular}{|c|c|c|c|c|c|c|}
\hline Group & Dose & \multicolumn{4}{|c|}{ Reaction time in seconds (Mean \pm SEM) } & $\begin{array}{c}\text { \% increase in reaction } \\
\text { time after 60 minutes }\end{array}$ \\
\hline & & 0 & At 30 minutes & At 60 minutes & At 90 minutes & \\
\hline Control & $10 \mathrm{ml} / \mathrm{kg}$ & $3.07 \pm 0.050$ & $3.25 \pm 0.050$ & $3.28 \pm 0.040$ & $3.35 \pm 0.040$ & 6.84 \\
\hline Standard Morphine & $2.5 \mathrm{mg} / \mathrm{kg}$ & $3.27 \pm 0.049$ & $6.68 \pm 0.130$ & $6.75 \pm 0.056$ & $6.27 \pm 0.080$ & \\
\hline Acetone extract & $300 \mathrm{mg} / \mathrm{kg}$ & $3.15 \pm 0.085$ & $3.47 \pm 0.067$ & $3.92 \pm 0.065$ & $4.27 \pm 0.067$ & \\
\hline Acetone extract & $500 \mathrm{mg} / \mathrm{kg}$ & $3.02 \pm 0.091$ & $3.55 \pm 0.067$ & $4.65 \pm 0.076$ & $4.92 \pm 0.079$ & 24.44 \\
\hline Methanol extract & $300 \mathrm{mg} / \mathrm{kg}$ & $2.98 \pm 0.087$ & $3.62 \pm 0.065$ & $3.95 \pm 0.067$ & $4.37 \pm 0.049$ & 53.97 \\
\hline Methanol extract & $500 \mathrm{mg} / \mathrm{kg}$ & $3.06 \pm 0.056$ & $3.77 \pm 0.033$ & $4.43 \pm 0.067$ & $4.75 \pm 0.076$ & 32.55 \\
\hline Aqueous extract & $300 \mathrm{mg} / \mathrm{kg}$ & $3.18 \pm 0.265$ & $3.75 \pm 0.343$ & $4.48 \pm 0.270$ & $4.72 \pm 0.169$ & 44.77 \\
\hline Aqueous extract & $500 \mathrm{mg} / \mathrm{kg}$ & $3.05 \pm 0.167$ & $4.23 \pm 0.249$ & $4.95 \pm 0.362$ & $5.22 \pm 0.179$ & 40.88 \\
\hline
\end{tabular}

All values are expressed as mean \pm SEM $(n=6) ; p<0.05$ denotes significance

Table 3: Effect of Drug Treatments upon Central Analgesic Activity using Hot Plate Model

\begin{tabular}{|c|c|c|c|c|c|c|}
\hline Group & Dose & \multicolumn{3}{|c|}{ Reaction time in second (Mean \pm SEM) } & $\begin{array}{c}\text { \% increase in reaction } \\
\text { time after 60 minutes }\end{array}$ \\
\hline & & 0 & 30 minutes & 60 minutes & 90 minutes & \\
\hline Control & $10 \mathrm{ml} / \mathrm{kg}$ & $3.67 \pm 0.049$ & $3.55 \pm 0.043$ & $3.48 \pm 0.054$ & $3.62 \pm 0.060$ & \\
\hline Std Morphine & $2.5 \mathrm{mg} / \mathrm{kg}$ & $3.55 \pm 0.043$ & $7.00 \pm 0.076$ & $7.38 \pm 0.060$ & $6.12 \pm 0.095$ & \\
\hline Acetone extract & $300 \mathrm{mg} / \mathrm{kg}$ & $3.57 \pm 0.126$ & $4.10 \pm 0.134$ & $5.43 \pm 0.080$ & $5.77 \pm 0.126$ & 107.89 \\
\hline Acetone extract & $500 \mathrm{mg} / \mathrm{kg}$ & $3.72 \pm 0.060$ & $5.20 \pm 0.097$ & $5.93 \pm 0.076$ & $6.65 \pm 0.760$ & 52.10 \\
\hline Methanol extract & $300 \mathrm{mg} / \mathrm{kg}$ & $3.53 \pm 0.760$ & $3.92 \pm 0.098$ & $4.47 \pm 0.095$ & $4.90 \pm 0.086$ & 59.41 \\
\hline Methanol extract & $500 \mathrm{mg} / \mathrm{kg}$ & $3.63 \pm 0.056$ & $4.47 \pm 0.088$ & $5.25 \pm 0.092$ & $5.53 \pm 0.880$ & 26.63 \\
\hline Aqueous extract & $300 \mathrm{mg} / \mathrm{kg}$ & $3.68 \pm 0.070$ & $4.97 \pm 0.182$ & $5.87 \pm 0.156$ & $6.20 \pm 0.137$ & \\
\hline Aqueous extract & $500 \mathrm{mg} / \mathrm{kg}$ & $3.43 \pm 0.167$ & $5.73 \pm 0.071$ & $6.45 \pm 0.143$ & $6.93 \pm 0.076$ & 59.62 \\
\hline
\end{tabular}

All values are expressed as mean \pm SEM $(n=6) ; p<0.05$ denotes significance

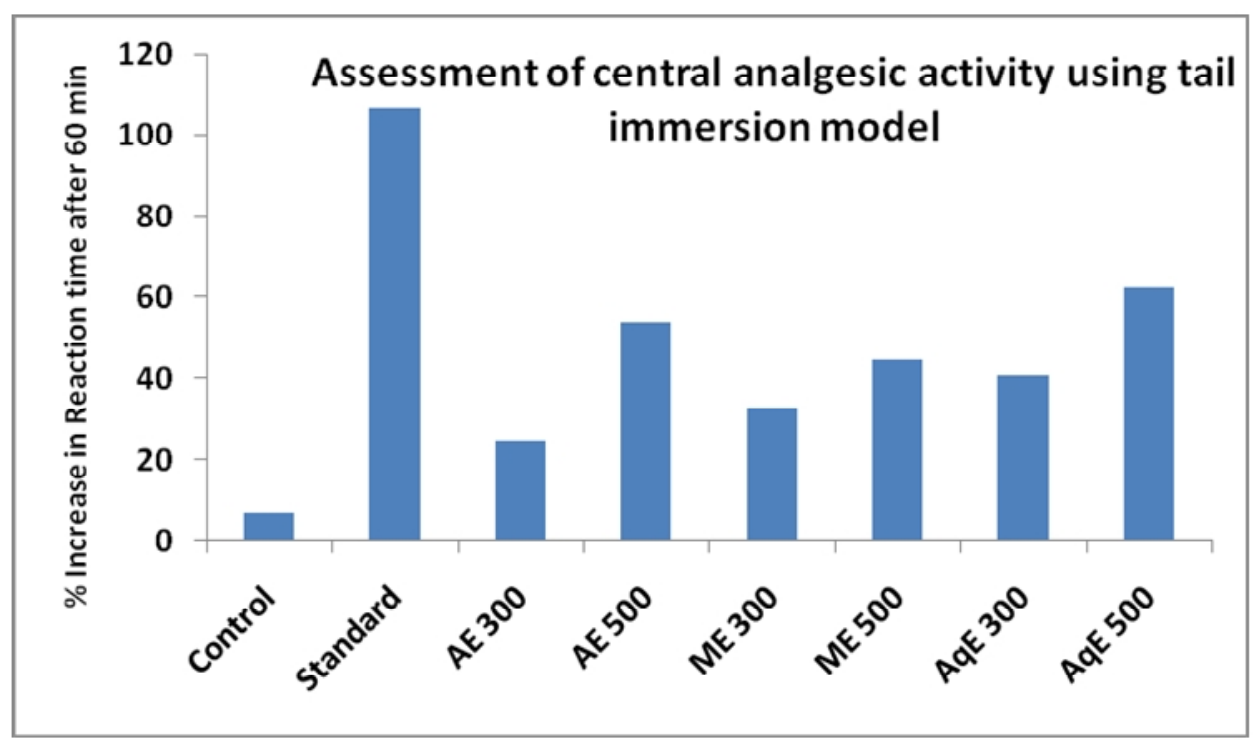

Figure 1: Central analgesic activity using tail immersion method 


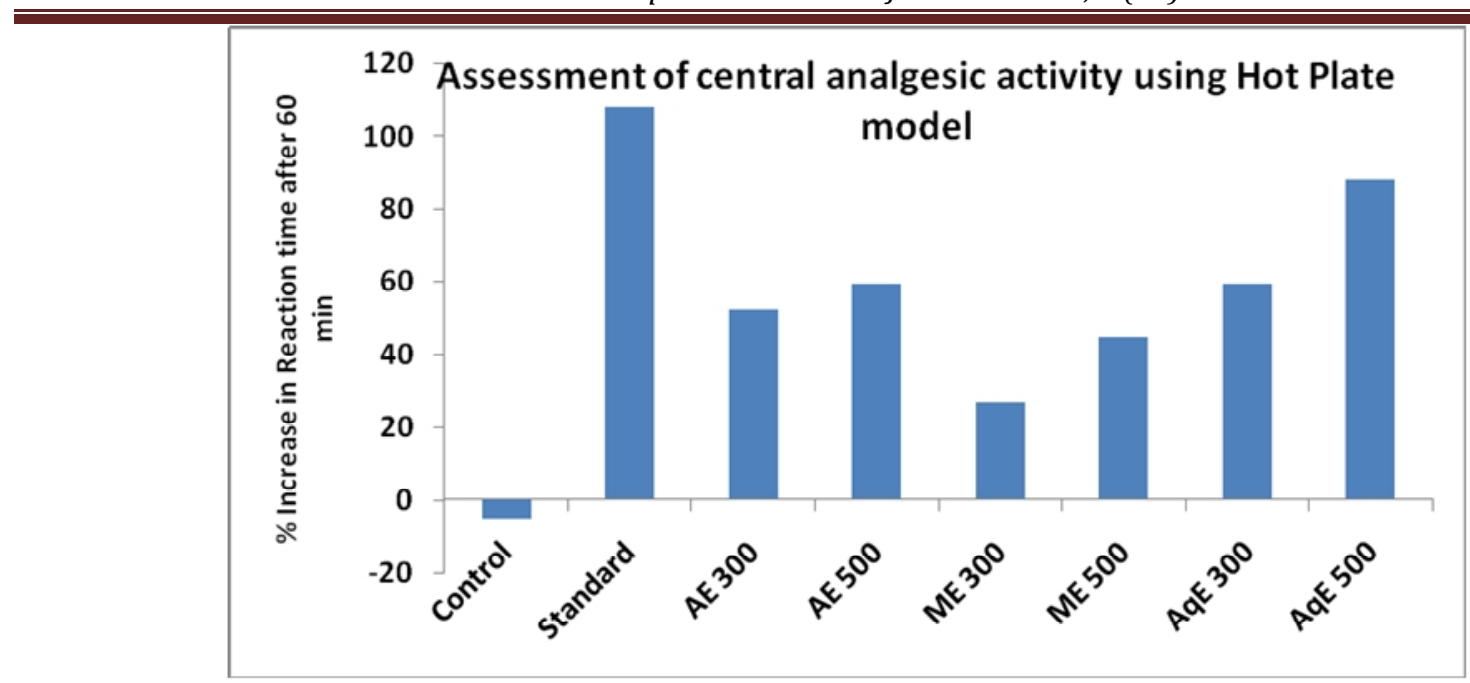

Figure 2: Central analgesic activity using Hot Plate method

\section{Acute Toxicity Study}

The animals tested during acute toxicity tests up to the dose of $2000 \mathrm{mg} / \mathrm{kg}$ showed no significant toxic symptoms like sedation, convulsion, diarrhoea, irritation, etc. and no signs of behavioural changes. No mortality was reported up to $24 \mathrm{~h}$ and even later during the subsequent 14 days at $2000 \mathrm{mg} / \mathrm{kg}$ dose.

\section{Central analgesic effect \\ Tail immersion method}

The results obtained during the tail immersion method have been shown in Table 2 and Figure 1. In case of acetone extract, the latency increased from $3.15 \mathrm{sec}$ to $3.92 \mathrm{sec}$ and from $3.02 \mathrm{sec}$ to $4.65 \mathrm{sec}$ respectively in case of the 300 and $500 \mathrm{mg} / \mathrm{kg}$ dosages after 60 minutes; while in case of the methanol extract, it increased from $2.98 \mathrm{sec}$ to $3.95 \mathrm{sec}$, and from $3.06 \mathrm{sec}$ to 4.43 over this period and in case of the aqueous extract, the increase over the corresponding period was from $3.18 \mathrm{sec}$ to $4.48 \mathrm{sec}$ and from $3.05 \mathrm{sec}$ to $4.95 \mathrm{sec}$. In comparison, the latency increased from $3.27 \mathrm{sec}$ to 6.75 sec in case of the standard drug group while the control group showed an increase from $3.07 \mathrm{sec}$ to only $3.28 \mathrm{sec}$ during this period of 60 minutes. The percentage increase in reaction time after oral administration of the drug and giving of thermal stimulus to the animals in case of the tail immersion method up to 60 minutes was $106.42 \%$ in case of the standard group, $24.44 \%$ and $53.97 \%$ in case of the acetone extracts $(300 \mathrm{mg} / \mathrm{kg}$ and $500 \mathrm{mg} / \mathrm{kg}$ dosage respectively); $32.55 \%$ and $44.77 \%$ in case of the methanol extracts and $40.88 \%$ and $62.29 \%$ in case of the aqueous extracts. During the same period, the control group showed only $6.84 \%$ increase in reaction time, indicating significant impact of the test drugs and standard drug during the experiment. The results indicated that all the extracts exhibited significant central analgesic effect at both the doses of $300 \mathrm{mg} / \mathrm{kg}$ and $500 \mathrm{mg} / \mathrm{kg}$ as compared to the control group. Comparing between the two drug doses, the analgesic efficacy was greater at the higher drug dose in case of all the extracts, as was expected. Among the three extracts, the highest central analgesic effect was observed in case of the aqueous extract, followed by the acetone extract and the lowest effect was seen in case of the methanol extract. The efficacy at higher dosage of the aqueous extract was assessed to be comparable but lower compared to the standard drug. The data showed significant progressive increases in the reaction time in case of all extracts at both the 300 and $500 \mathrm{mg} / \mathrm{kg}$ doses up to 90 minutes after the drug administration. In comparison, the standard drug Morphine sulphate exhibited increases in reaction time only up to 60 minutes after the drug was administered, followed by decreased reaction time at 90 minutes. Thus, the central analgesic effect was persisting for a longer time in case of all the drug extracts than in case of the standard drug.

\section{Hot Plate method}

The results of the hot plate method have been shown in Table 3 and Figure 2. In case of the acetone extract, latency in hind paw licking after 60 minutes of drug administration increased from $3.57 \mathrm{sec}$ to $5.43 \mathrm{sec}$ and from $3.72 \mathrm{sec}$ to $5.93 \mathrm{sec}$ respectively in case of the 300 and $500 \mathrm{mg} / \mathrm{kg}$ dosages. In case of the methanol extract, it increased from $3.53 \mathrm{sec}$ to $4.47 \mathrm{sec}$ and from $3.63 \mathrm{sec}$ to $5.25 \mathrm{sec}$ over the corresponding period while in case of the aqueous extract, the observed increase was from $3.68 \mathrm{sec}$ to $5.87 \mathrm{sec}$ and from $3.43 \mathrm{sec}$ to $6.45 \mathrm{sec}$ for $300 \mathrm{mg} / \mathrm{kg}$ and $500 \mathrm{mg} / \mathrm{kg}$ drug dosages respectively. In comparison, the latency increased from 3.55 sec to $7.38 \mathrm{sec}$ in case of the standard drug group while the control group actually showed a decrease from $3.67 \mathrm{sec}$ to $3.48 \mathrm{sec}$ during this period of 60 minutes. The percentage increase in reaction time after oral administration of the drug and giving of thermal stimulus to the animals in case of the hot plate method up to 60 minutes was $107.89 \%$ in case of the standard group, $52.10 \%$ and $59.41 \%$ in case of the acetone extracts $(300 \mathrm{mg} / \mathrm{kg}$ and $500 \mathrm{mg} / \mathrm{kg}$ dosage respectively); $26.63 \%$ and $44.62 \%$ in case of the methanol extracts and $59.51 \%$ and $88.05 \%$ in case of the aqueous extracts. During the same period, the control group showed a $5.18 \%$ decrease in reaction time, indicating significant impact of the test drugs and standard drug during the experiment. The results indicated that while all the three extracts exhibited significant and noticeable central analgesic effect at both the doses of $300 \mathrm{mg} / \mathrm{kg}$ and $500 \mathrm{mg} / \mathrm{kg}$ as compared to the control group, the analgesic effect was definitely greater at the higher drug dose. Among the three extracts, the highest central analgesic effect was observed in case of the aqueous extract, followed by the acetone extract and the lowest effect was seen in case of the methanol extract. The efficacy at higher dosage of the aqueous extract was assessed to be comparable but a little lesser than that of the standard drug. The results of the hot plate test showed a 
progressive increase in the reaction time in case of all the extracts at both the 300 and $500 \mathrm{mg} / \mathrm{kg}$ doses up to 90 minutes after the drug administration. In comparison, the standard drug Morphine sulphate exhibited increases in reaction time only up to 60 minutes after the drug was administered, followed by decreased reaction time at 90 minutes.

\section{DISCUSSION}

The body has an endogenous analgesic system that prevents excess pain from interfering with the normal body functions. Depression of pain sensations occurs within the dorsal horn of the spinal cord where the primary pain fibres, which transmit pain sensations from the periphery, synapse with neurons that transmit pain to the higher centres. There appear to be two mechanisms by which the transmissions of pain sensations are depressed; these include hyper polarization of interneurons within the dorsal cord and depressing the release of the neurotransmitters associated with pain transmission. Activation of the analgesic mechanisms results from an interaction between specific neurotransmitters, such as enkephalin, serotonin, or norepinephrine, and specific receptors located on the neurons that transmit pain. The spinal analgesic mechanisms can be activated by either pain or non-painful sensations arriving from the periphery or by supraspinal mechanisms. The supraspinal mechanisms originate in specific structures within the brainstem that include the periaqueductal gray matter, locus ceruleus, and nuclei in the medulla. These systems are activated either by ascending pain impulses or by higher centers such as the cortex or hypothalamus that, in turn, activate the spinal analgesic systems. There are three systems associated with activation of the supraspinal mechanisms. These include the opioid system associated with the release of the endorphins, the adrenergic system associated with the release of norepinephrine, and the serotonergic system associated with the release of serotonin. The interaction between these systems activates the spinal analgesic system. When the endogenous analgesic systems fail to control pain, analgesic drugs can be used to enhance the endogenous systems. Opiate drugs, such as morphine, interact with opioid receptors and produce analgesia by the same mechanisms as enkephalin, i.e., hyperpolarization of interneurons and depressing the release of transmitters associated with transmission of pain. In addition, morphine can interact with opioid receptors located in the supraspinal structures and activate the supraspinal system. Adrenergic drugs that interact with specific receptors also produce analgesia and it has been suggested that morphine interacts with the adrenergic system to produce analgesia ${ }^{10,14,15}$. The Hot plate and tail immersion methods indicated that the central analgesic effect of the 3 extracts was significant and dose dependent as revealed by the increased reaction time after giving thermal stimulus to the mice. The latency in reaction time continued up to 90 minutes after the drug administration in case of both the 300 $\mathrm{mg} / \mathrm{kg}$ and the $500 \mathrm{mg} / \mathrm{kg}$ extracts, revealing sustained and pronounced central analgesic effect when compared with the control group. However, its overall central analgesic effect was a little lower when compared with the standard drug Morphine over different time periods, the higher test drug dosage resulting in a more pronounced effect with a similar pattern of results. Among the three extracts, highest efficacy was observed in case of the Aqueous extract, followed by the Acetone extract and comparatively lower impact in case of the Methanol extract. It has been widely reported that all flavonoid compounds possess analgesic activity, due to inhibition of prostaglandin synthesis and consequent decreased stimulation of nociceptors. Flavonoids are thought to interact with the cyclooxigenase system, so as to interfere with arachidonic acid synthesis and inhibit the production of prostaglandins ${ }^{16}$. The central analgesic effect of the test drugs could be possibly attributed to the presence of flavonoids in them.

\section{ACKNOWLEDGEMENTS}

This research work was supported by grants from the University Grants Commission, New Delhi, India and we are grateful for that. The authors are thankful to the Botanical Survey of India, West Bengal, India for identification of plant material and to the Department of Dravyaguna, IPGAE and R, Kolkata, India for providing their laboratory facilities and necessary instruments for performing experiments.

\section{REFERENCES}

1. Sharma PV. Dravyaguna Vijnana. Varanasi, India: Chaukhamba Bharati Academy; 1995. p. 617-619. PMid:7695615

2. Sharma PC, Yelne MB, Dennis TJ. Database on medicinal Plants used in Ayurveda. New Delhi: Central Council for Research in Ayurveda and Siddha, Department of ISM and H, Ministry of Health and Family Welfare (Govt. of India); 2005. p. 3, 76-87.

3. Chatterjee A, Pakrashi SC. The treatise on Indian medicinal plants. New Delhi: National Institute of Science Communication and Information Resources, CSIR; 2006. p. 46-47.

4. Pradhan P, Joseph L, Gupta V, Chulet R, Arya H, Verma R, et al. Saraca asoca (Ashoka): A Review. J Chem Pharm Res 2009; 1(1): 6271.

5. Sasmal S, Majumdar S, Gupta M, Mukherjee A, Mukherjee PK. Pharmacognostical, phytochemical and pharmacological evaluation for the antipyretic effect of the seeds of Saraca asoca Roxb. Asian Pacific J of Tropical Biomed 2012; 2(10): 782-786. http://dx.doi.org/10.1016/ S2221-1691(12)60229-9

6. Evans WC. Trease and Evans Pharmacognosy. $16^{\text {th }}$ ed. London: Saunders Elsevier; 2009.

7. Kokate CK. Practical Pharmacognosy. $4^{\text {th }}$ ed. New Delhi: Vallabh Prakashan; 2005. p. 107-111.

8. Harborne JB. Phytochemical Methods. A Guide to Modern Techniques of Plant Analysis. $2^{\text {nd }}$ ed. London: Chapmann and Hall; 1984. p. 192.

9. Ghosh MNH and Book of Experimental Pharmacology. $4^{\text {th }}$ ed. Kolkata: Hilton and Company; 2008.

10. Shukla SH, Mistry HA, Patel VG, Jogi BV. Pharmacognostical, preliminary phytochemical Studies and analgesic activity of Amomum subulatum Roxb. Pharma Science Monitor 2010; 1(1): 90-102.

11. OECD. Acute Oral Toxicity - Acute Toxic Class Method. Paris: OECD Guideline 423 for Testing of Chemicals; 2001. p. 1-14.

12. Veerappana A, Miyazakib S, Kadarkaraisamyc M, Ranganathana D. Acute and sub-acute toxicity studies of Aegle marmelos Corr., An Indian medicinal plant. Phytomedicine 2007; 14: 209-215. http://dx.doi. org/10.1016/j.phymed.2006.05.004 PMid:16860551

13. Kumar JP, Shankar NB. Analgesic activity of mollugo pentaphylla Linn. by tail immersion method. Asian J. Pharm. Clin. Res 2009; 2(1): 61-63.

14. Nanda BK, Jena J, Rath B, Behera BR. Analgesic and Antipyretic activity of whole parts of Sphaeranthus indicus Linn. Journal of Chemical and Pharmaceutical Research 2009; 1(1): 207-212.

15. Veerappan A, Miyazaki S, Dhananjayan R. Studies on the antiinflammatory, antipyretic and analgesic properties of the leaves of Aegle marmelos. Corr. J. Ethnopharmacol 2005; 96(1-2): 159-163. http://dx. doi.org/10.1016/j.jep.2004.09.013 PMid:15588665

16. Gupta, M., Sasmal, S., Majumdar, S., Mukherjee, A. HPLC profiles of standard Phenolic Compounds present in medicinal plants. International Journal of Pharmacognosy and Phytochemical Research, 2012;4(3): 162-167.

\section{Cite this article as:}

Mradu Gupta, Saumyakanti Sasmal, Arup Mukherjee Gupta. Central antinociceptive effect of different extracts of Saraca asoca seeds assessed using hotplate and tail immersion methods. Int. Res. J. Pharm. 2013; 4(10):94-98 http://dx.doi.org/10.7897/2230-8407.041021 